\title{
Keefektifan tiga jenis perangkap serangga untuk deteksi serangga hama gudang yang menyerang bungkil kopra
}

\author{
Effectiveness of three types of insect traps for detection of \\ insect pest of stored copra meal \\ Diana Budiman ${ }^{1}$, Dadang' ${ }^{2}$ Idham Sakti Harahap ${ }^{2}$ \\ 'Balai Besar Karantina Pertanian \\ Gedung Karantina Pertanian Bandar Udara Internasional Soekarno Hatta, Tangerang 15126 \\ ${ }^{2}$ Departemen Proteksi Tanaman, Fakultas Pertanian, Institut Pertanian Bogor \\ Jalan Kamper, Kampus IPB Dramaga, Bogor 16680
}

(diterima April 2019, disetujui November 2019)

\begin{abstract}
ABSTRAK
Serangga hama gudang dapat menyebabkan penolakan konsumen dan kerugian ekonomi berkaitan dengan masalah mutu atau persyaratan fitosanitari. Keefektifan perangkap serangga pada komoditas bungkil kopra yang disimpan masih belum banyak diketahui. Penelitian dilakukan untuk menentukan keefektifan tiga jenis perangkap serangga dalam mendeteksi serangga hama gudang pada bungkil kopra. Perangkap serangga yang diuji terdiri atas perangkap jebakan, perangkap colokan, dan perangkap cahaya dari lampu ultraviolet (UV) blacklight dan LED (light emiting diode). Penelitian dilakukan di Laboratorium Entomologi SEAMEO BIOTROP dan dua gudang penyimpanan bungkil kopra (GPBK) di Bitung, Sulawesi Utara. Percobaan di laboratorium menggunakan rancangan acak lengkap faktorial yang terdiri atas dua faktor dan empat ulangan. Faktor pertama adalah jenis perangkap serangga, yaitu perangkap jebakan, perangkap colokan, dan perangkap colokan dengan LED UV dan faktor kedua adalah spesies serangga, yaitu Tribolium castaneum (Herbst) dan Lasioderma serricorne (Fabricius). Percobaan di gudang penyimpanan menggunakan rancangan acak kelompok tersarang, yaitu spesies serangga terperangkap tersarang pada masing-masing perangkap serangga yang digunakan di GPBK. Hasil pengujian di laboratorium menunjukkan perangkap colokan lebih banyak menangkap serangga $(30,4 \%)$ yang berbeda nyata dibandingkan dengan perangkap jebakan (17,3\%), tetapi serangga yang tertangkap tidak berbeda nyata antara perangkap colokan dengan perangkap colokan dengan LED UV (21\%). Pengujian di gudang menunjukkan bahwa perangkap colokan lebih efektif dalam memerangkap T. castaneum dan Tenebroides mauritanicus dibandingkan perangkap serangga lainnya, sedangkan perangkap colokan dengan LED UV lebih efektif dalam mendeteksi L. serricorne and Necrobia rufipes (Fabricius) di GPBK.
\end{abstract}

Kata kunci: bungkil kopra, perangkap cahaya, perangkap colokan, perangkap jebakan

\begin{abstract}
Stored product insect can cause consumer rejection and economic loss due to quality concerns and phytosanitary regulation. Insect traps have been regularly used as a control method, however its effectiveness on controlling stored copra meal insect pests is not yet known. This study was carried out to compare the effectiveness of three types of insect traps for detection of insect pests of copra meal. The three types of insect traps were pitfall trap, probe trap, and ultraviolet (UV) light trap (blacklight and LED-light emiting diodes). Research was conducted at Laboratory of Entomology SEAMEO BIOTROP, Bogor and two storage facilities of copra meal in North Sulawesi. Laboratory experiment was conducted using completely randomized design with two factors and four replications. The first

*Penulis korespondensi: Diana Budiman. Balai Besar Karantina Pertanian Soekarno Hatta, Gedung Karantina Pertanian Bandar Udara Internasional Soekarno Hatta, Tangerang, Banten 15126, Tel:021-507930, Faks: 021-500623, 5507930, Email: di5budiman@gmail.com
\end{abstract}




\begin{abstract}
factor was the types of insect traps (pitfall trap, probe trap, and probe trap with UV LED) and the second factor was insect species (Lasioderma serricorne (Herbst) and Tribolium castaneum (Fabricius)). The experiment at storage facilities was conducted with nested block design where the insect species trapped were nested in the insect traps. The result of laboratory experiment showed that the probe trap captured more insects (30.4\%) significantly higher than pitfall trap $(17.1 \%)$, however there was no significant difference of number of insects trapped in probe trap with and without UV LED. In addition the probe trap captured more T. castaneum and Tenebroides mauritanicus than other type of insects trap, but probe trap with UV LED was more effective to detect $L$. serricorne and Necrobia rufipes (Fabricius) in the stored copra meal.
\end{abstract}

Key words: copra meal, light trap, pitfall trap, probe trap

\section{PENDAHULUAN}

Indonesia merupakan negara eksportir bungkil kopra terbesar kedua di dunia setelah Filipina dengan pangsa pasar 30,88\% (Damanik 2000). Pada tahun 2015 Indonesia mengekspor bungkil kopra sebanyak 281,482 ton. Komoditas pertanian tersebut diekspor ke beberapa negara tujuan, antara lain Korea Selatan (60\%), India (35\%), dan Vietnam (4\%) (Dirjenbun 2017). Bungkil kopra sebagian besar dihasilkan dari Provinsi Sulawesi Utara, yaitu sebesar 48\% dari total produksi nasional pada tahun 2012 (Kaunang 2013).

Bungkil kopra yang disimpan dapat terinfestasi oleh Trigonogenius globulum (Coleoptera: Ptinidae), Tribolium castaneum (Coleoptera: Tenebrionidae), dan Lasioderma serricorne (Coleoptera: Anobiidae) (USDA 1991; Semple 1985). T. castaneum dan L. serricorne merupakan serangga kosmopolit yang banyak ditemukan di Indonesia, sedangkan daerah sebaran T. globulum masih terbatas di Benua Amerika dan Afrika.

Perangkap serangga dirancang berdasarkan perilaku dan ketertarikan serangga terhadap cahaya, bentuk, dan warna tertentu. Perangkap serangga yang banyak digunakan untuk mendeteksi keberadaan serangga pada komoditas pertanian yang disimpan di antaranya adalah perangkap jebakan (pitfall trap), perangkap colokan (probe trap), dan perangkap cahaya (light trap). Perangkap colokan merupakan modifikasi dari perangkap jebakan yang dirancang khusus untuk komoditas pertanian yang disimpan dalam bentuk tepung atau biji-bijian. Hasil penelitian menunjukkan bahwa perangkap colokan lebih efektif dan sensitif dalam mendeteksi serangga hama gudang yang menyerang biji gandum yang disimpan dalam silo dibandingkan dengan pengambilan contoh (Toews et al. 2005).
Ekspor komoditas pertanian termasuk bungkil kopra harus memenuhi persyaratan fitosanitari dan standar keamanan pangan yang ditetapkan oleh negara mitra dagang. Serangga yang ditemukan pada bungkil kopra yang diekspor dapat menyebabkan kerugian pada pihak eksportir akibat biaya pengapalan kembali (penolakan) atau re-fumigasi di tempat tujuan. Sistem sertifikasi fitosanitari untuk ekspor produk pertanian berpedoman pada sistem yang berbasis in-line inspection melalui penerapan mitigasi resiko terbawanya organisme pengganggu tumbuhan (OPT) dan kontaminasi cemaran berbahaya mulai dari tempat produksi sampai ke tempat pengiriman (BKP 2014). Sejalan dengan hal tersebut, jenis perangkap serangga yang akan digunakan pada gudang penyimpanan bungkil kopra perlu diketahui kelayakan dan keefektifannya. Penelitian dilakukan untuk menentukan keefektifan dari perangkap jebakan, perangkap colokan, dan perangkap cahaya terhadap serangga hama gudang yang menyerang komoditas bungkil kopra di laboratorium dan di gudang penyimpanan bungkil kopra.

\section{BAHAN DAN METODE}

\section{Tempat dan waktu penelitian}

Penelitian pada gudang penyimpanan bungkil kopra dilaksanakan dari bulan Desember 2016 sampai Februari 2017 di Kota Bitung, Sulawesi Utara. Identifikasi serangga dilakukan di Laboratorium Balai Karantina Pertanian Kelas I Manado, Sulawesi Utara. Penelitian di laboratorium dilakukan dari bulan November 2017 sampai bulan Januari 2018 di Southeast Asian Regional Centre for Tropical Biology (SEAMEO BIOTROP). 


\section{Metode penelitian}

Penelitian dilakukan di laboratorium dan di gudang penyimpanan bungkil kopra. Penelitian yang dilakukan di laboratorium menggunakan rancangan acak lengkap faktorial terdiri atas 2 faktor dengan 4 ulangan. Faktor pertama adalah jenis perangkap dengan 3 taraf, yaitu perangkap jebakan, perangkap colokan, perangkap colokan dengan LED (light emiting diode) ultraviolet (UV) dan faktor kedua adalah jenis serangga, yaitu $T$. castaneum dan L. serricorne. Penelitian yang dilakukan di dua gudang penyimpanan bungkil kopra menggunakan rancangan acak kelompok tersarang, yaitu spesies serangga terperangkap tersarang pada perangkap serangga dengan minggu pengamatan sebagai ulangan.

\section{Rancangan perangkap}

Perangkap jebakan. Perangkap jebakan terbuat dari bahan plastik berukuran panjang $9,8 \mathrm{~cm}$, diameter bagian atas $8,7 \mathrm{~cm}$ dan diameter bagian bawah $6 \mathrm{~cm}$ (Gambar 1A). Penutup pada bagian atas perangkap tersebut terdapat lubang-lubang sebanyak 64 buah dengan diameter $3 \mathrm{~mm}$. Perangkap jebakan tersebut diolesi perekat berupa vaselin pada sisi bagian dalam dan alasnya.

Perangkap colokan. Perangkap colokan berbentuk tabung silinder dari bahan plastik dengan panjang $30 \mathrm{~cm}$ dan diameter 2,6 $\mathrm{cm}$ (Gambar 1B). Perangkap tersebut diletakkan secara vertikal pada komoditas bungkil kopra terdiri atas tiga bagian, yaitu bagian atas $(9 \mathrm{~cm})$, bagian tengah $(16 \mathrm{~cm})$ dan bagian bawah yang berbentuk kerucut terbalik $(5 \mathrm{~cm})$. Perangkap colokan bagian atas tidak terdapat lubang-lubang, sedangkan di bagian tengah terdapat lubang-lubang sebanyak 274 buah dengan ukuran diameter $3 \mathrm{~mm}$.

Perangkap colokan dengan LED UV. Perangkap colokan dengan LED UV merupakan kombinasi antara perangkap colokan dan light trap menggunakan lampu senter $(8 \mathrm{~cm} \times 2,5 \mathrm{~cm})$ yang memiliki 9 buah LED UV berukuran $5 \mathrm{~mm}$ $(25 \mu \mathrm{A} / 3,3$ Volt) (Gambar 1C).

Light trap. Light trap yang digunakan terdiri atas lampu blacklight (T5 8 Watt BLB) berukuran $30 \mathrm{~cm}$ dan kertas karton berwarna putih yang diolesi lem perekat berukuran $35 \mathrm{~cm} \mathrm{x} 30 \mathrm{~cm}$, kedua komponen tersebut diletakan pada kayu triplek berukuran $40 \mathrm{~cm}$ x $50 \mathrm{~cm}$ (Papadopoulou $\&$ Buchelos 2002) (Gambar 1D).

\section{Pengujian perangkap serangga di laboratorium}

Perbanyakan serangga $T$. castaneum dan L. serricorne. Serangga $T$. castaneum dan $L$. serricorne yang digunakan berasal dari koleksi serangga Laboratorium Entomologi SEAMEO BIOTROP, Bogor. Sebanyak 500 imago dari masing-masing serangga dimasukkan ke dalam stoples kaca berukuran $26 \mathrm{~cm} \mathrm{x} 15 \mathrm{~cm}$ (diameter) yang telah diisi dengan 250 g makanan serangga, yaitu tepung terigu untuk $T$. castaneum dan oatmeal untuk L. serricorne. Setelah 24 jam imago serangga tersebut dikeluarkan dari media makanannya. Serangga dibiakkan massal dalam stoples kaca pada ruangan dengan suhu berkisar antara $25-32{ }^{\circ} \mathrm{C}$, kelembapan relatif (RH) antara 59-89\%. Serangga uji yang digunakan pada percobaan di laboratorium adalah imago $T$. castaneum yang berumur 12 hari dan imago $L$. serricorne berumur 2-3 hari.

Pemasangan perangkap. Percobaaan dilakukan pada wadah (ember) plastik berwarna hijau (39 cm x $38 \mathrm{~cm}$ (diameter)) yang telah diisi dengan $5 \mathrm{~kg}$ bungkil kopra. Bungkil kopra yang digunakan berasal dari distributor pakan ternak di Bogor. Sebanyak 30 individu serangga uji dimasukkan ke dalam masing-masing unit percobaan dan diaklimatisasi selama 48 jam. Pemasangan perangkap serangga dilakukan di
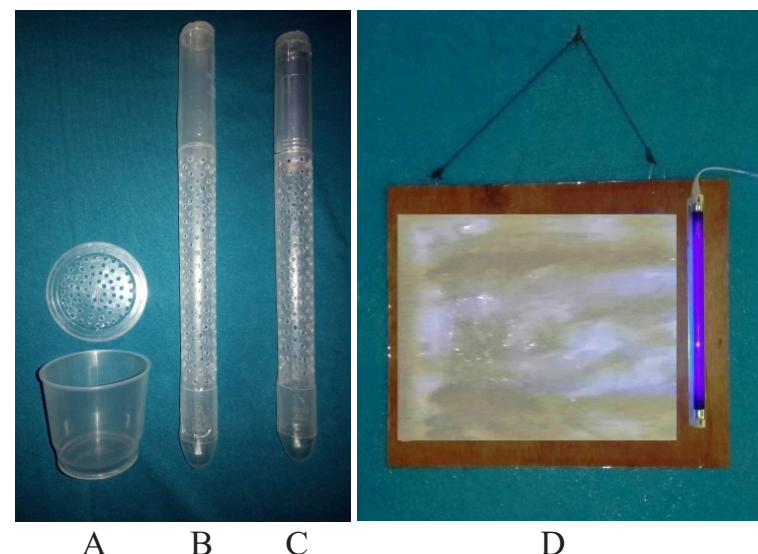

Gambar 1. Perangkap jebakan (A); perangkap colokan (B); perangkap colokan LED UV (C); light trap lampu blacklight (D). 
bagian tengah pada masing-masing wadah plastik, kemudian ditutup dengan kain kasa (Gambar 2A).

Pengamatan. Pengamatan serangga yang tertangkap dilakukan setelah perangkap serangga dipasang selama 72 jam. Keefektifan perangkap serangga didefinisikan sebagai proporsi serangga yang tertangkap dari total populasi serangga per unit volume selama periode tertentu (Buckman \& Campbell 2013). Data pengamatan berupa persentase rasio antara serangga yang tertangkap dan jumlah serangga yang dilepaskan.

$$
\mathrm{a}=\frac{n_{i}}{N} \times 100 \text {, dengan }
$$

a: serangga yang tertangkap (\%); $\mathrm{n}_{\mathrm{i}}$ : serangga yang tertangkap per jenis perangkap serangga; $\mathrm{N}$ : serangga uji (30 individu).

\section{Pengujian perangkap serangga di gudang penyimpanan bungkil kopra}

Kondisi umum gudang penyimpanan bungkil kopra. Gudang penyimpanan bungkil kopra (GA) terletak sekitar $20 \mathrm{~km}$ dari gudang penyimpanan bungkil kopra kedua (GB). GA memiliki luas $40 \mathrm{~m}$ x $50 \mathrm{~m}$ terletak di dalam kawasan pelabuhan yang berfungsi sebagai tempat penyimpanan bungkil kopra yang akan diekspor.

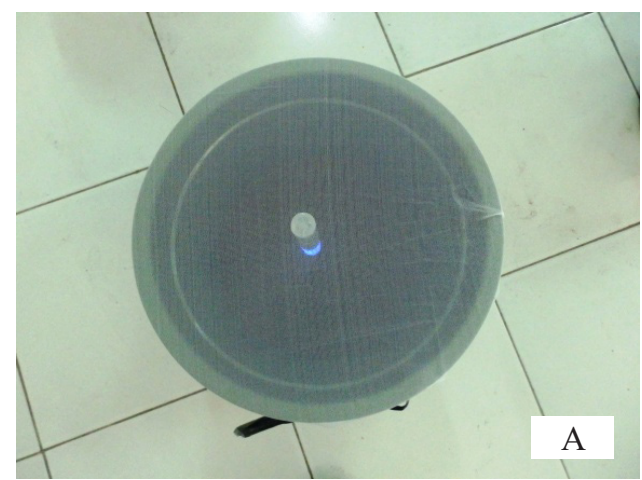

GB memiliki luas $40 \mathrm{~m}$ x $60 \mathrm{~m}$ terletak di dalam kompleks industri pengolahan minyak kelapa. Bungkil kopra di GA sebelumnya telah tersimpan selama tiga bulan pada saat dilakukannya penelitian, sedangkan di GB terdapat bungkil kopra sepanjang tahun.

Pemasangan perangkap. Perangkap serangga hama gudang dipasang pada hari yang sama di kedua gudang penyimpanan bungkil kopra (Tabel 1). Perangkap jebakan dan perangkap colokan diletakkan pada lereng tumpukan bungkil kopra pada ketinggian 1,5 meter dari lantai dan 1,5 meter dari dinding (Gambar 2B), sedangkan light trap dipasang pada ketinggian 1,8 meter dari lantai. Perangkap serangga tersebut diletakkan pada jarak antara 10-15 m (Buckman \& Campbell 2013).

Pengamatan. Perangkap serangga yang dipasang pada kedua gudang penyimpanan bungkil kopra diamati setiap 3 atau 4 hari selama 8 minggu antara pukul 09.00-15.00. Kertas karton pada light trap dan baterai pada perangkap colokan dengan LED UV diganti dengan yang baru pada setiap waktu pengamatan, kemudian serangga yang terperangkap dimasukkan ke dalam botol koleksi. Setelah selesai diamati perangkap serangga

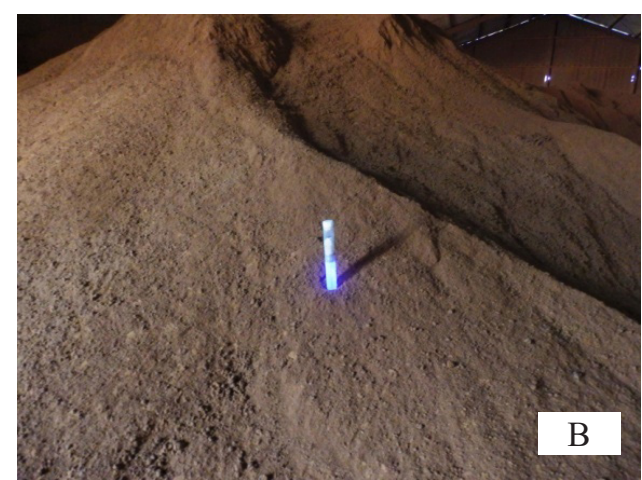

Gambar 2. Perangkap colokan dengan LED UV yang dipasang pada bungkil kopra di laboratorium (A) dan gudang penyimpanan $(\mathrm{B})$.

Tabel 1. Jenis perangkap serangga dan letak pemasangan di gudang penyimpanan bungkil kopra

\begin{tabular}{ll}
\hline No & Letak pemasangan perangkap serangga \\
\hline P1 & Perangkap jebakan pada permukaan bungkil kopra \\
P2 & Perangkap colokan pada permukaan bungkil kopra \\
P3 & Perangkap colokan LED UV pada permukaan bungkil kopra \\
P4 & Perangkap colokan $15 \mathrm{~cm}$ di bawah permukaan bungkil kopra \\
P5 & Perangkap colokan LED UV $15 \mathrm{~cm}$ di bawah permukaan bungkil kopra \\
P6 & Perangkap lampu blacklight $180 \mathrm{~cm}$ dari lantai gudang penyimpanan \\
\hline
\end{tabular}


tersebut dipasang kembali pada tempatnya semula. Serangga yang terperangkap dari masing-masing jenis perangkap kemudian dicatat dan diidentifikasi di laboratorium berdasarkan kunci identifikasi dari USDA (1991) dan Bousquet (1990).

\section{Analisis data}

Data pengamatan pengujian keefektifan perangkap serangga di laboratorium dilakukan transformasi data dengan menggunakan $\sqrt{ }(\mathrm{Y}+0,5)$ untuk normalitas data dan homogenitas ragam. Data dianalisis dengan uji analisis ragam (ANOVA) setelah pemeriksaan asumsi terpenuhi dengan menggunakan aplikasi Minitab versi 17. Hasil uji analisis ragam yang menunjukkan terdapat perbedaan di antara perlakuan dilakukan pengujian lanjutan dengan uji Tukey pada taraf nyata $5 \%$. Spesies serangga yang terperangkap dalam satu minggu selama 8 minggu pengamatan digunakan sebagai ulangan pada analisis data percobaan ( $\mathrm{n}$ imago/minggu) di gudang penyimpanan bungkil kopra. Data pengamatan di gudang penyimpanan bungkil kopra dilakukan transformasi data dengan menggunakan $\sqrt{ }(\mathrm{Y}+0,5)$ untuk normalitas data dan homogenitas ragam. Data rata-rata serangga tertangkap/minggu di gudang penyimpanan dibandingkan dengan uji t berdasarkan spesies dan jenis perangkap serangga yang sama (Baehaki et al. 2016).

\section{HASIL}

Keefektifan perangkap serangga di laboratorium

Hasil uji statistik keefektifan perangkap serangga yang dilakukan di laboratorium menunjukkan interaksi antara faktor jenis perangkap serangga dan faktor spesies serangga tidak berbeda nyata pada taraf $5 \%\left(\mathrm{~F}_{2,18}=0,52 ; \mathrm{P}=0,187\right)$, tetapi masing-masing faktor memberikan pengaruh yang nyata terhadap rata-rata persentase serangga yang tertangkap. Persentase rata-rata serangga yang tertangkap (T. castaneum dan L. serricorne) berdasarkan jenis perangkap menunjukkan bahwa serangga yang tertangkap pada perangkap colokan $(30,4 \%)$ berbeda nyata dengan perangkap jebakan $(17,1 \%)$, tetapi tidak berbeda nyata dengan perangkap colokan LED UV. Spesies serangga juga merupakan faktor utama yang menentukan persentase rata-rata serangga yang tertangkap. Serangga $L$. serricorne yang masuk pada semua jenis perangkap serangga secara signifikan lebih tinggi $(33,1 \%)$ dibandingkan dengan persentase rata-rata $T$. castaneum yang hanya sebesar $12,8 \%$ (Tabel 2).

\section{Keefektifan perangkap serangga di gudang penyimpanan bungkil kopra}

Serangga hama gudang yang tertangkap pada masing-masing gudang penyimpanan bungkil kopra memiliki kelimpahan dan komposisi spesies serangga yang berbeda. Serangga yang ditemukan pada GA dan GB hanya $T$. castaneum, jumlah $T$. castaneum yang tertangkap di GA lebih sedikit dibandingkan dengan GB. Total imago serangga yang tertangkap di GA terdapat 183 individu yang terdiri atas $T$. castaneum (81 individu), $L$. serricorne (58 individu) dan Necrobia rufipes (Coleoptera: Cleridae) sebanyak 44 individu, sedangkan di GB terdapat 557 individu serangga terdiri atas $T$. castaneum (379 individu) dan Tenebroides mauritanicus (Coleoptera; Trogossitidae) sebanyak 178 individu (Gambar 3).

Gambar 4 menunjukkan rata-rata serangga yang tertangkap ( $\mathrm{n} /$ minggu) berdasarkan jenis perangkap dan spesies serangga di gudang A penyimpanan bungkil kopra. Hasil uji analisis ragam menunjukkan jenis perangkap $\left(\mathrm{F}_{5,119}=\right.$

Tabel 2. Rata-rata persentase serangga terperangkap berdasarkan faktor percobaan jenis perangkap dan spesies serangga di laboratorium $( \pm \mathrm{SD})^{\mathrm{a}}$

\begin{tabular}{|c|c|c|c|}
\hline \multicolumn{4}{|c|}{ Persentase serangga terperangkap (\%) berdasarkan } \\
\hline \multicolumn{2}{|c|}{ Perangkap serangga } & \multicolumn{2}{|c|}{ Spesies serangga } \\
\hline $\mathrm{P} 1$ & $17,1 \pm 13,86 b$ & Tribolium castaneum & $12,8 \pm 10,62 b$ \\
\hline P2 & $30,4 \pm 13,04 \mathrm{a}$ & Lasioderma serricorne & $33,1 \pm 8,46 \mathrm{a}$ \\
\hline P3 & $21,3 \pm 13,18 \mathrm{ab}$ & & \\
\hline
\end{tabular}

${ }^{a}$ Angka yang diikuti oleh huruf yang sama pada satu kolom tidak berbeda nyata berdasarkan uji Tukey pada taraf 5\%. 
49,34; $\mathrm{P}=0,00)$ dan spesies serangga $\left(\mathrm{F}_{12,119}=\right.$ $8,25 ; \mathrm{P}=0,00)$ di gudang A memiliki rata-rata serangga tertangkap yang berbeda nyata pada taraf 5\%. Perangkap serangga P2 memiliki ratarata $T$. castaneum tertangkap yang lebih tinggi (3,9 imago/minggu) dibandingkan dengan jenis perangkap lainnya. Namun demikian, perangkap P2 secara signifikan memiliki rata-rata serangga $N$. rufipes dan L. serricorne tertangkap yang lebih rendah dibandingkan dengan jenis perangkap lainnya. Perangkap serangga P3 secara signifikan memiliki rata-rata serangga $N$. rufipes $(3,5$ imago/ minggu) dan $L$. serricorne (4,3 imago/minggu) tertangkap yang lebih tinggi dibandingkan dengan jenis perangkap lainnya (Tabel 3 ).

Gambar 5 menunjukkan rata-rata serangga yang tertangkap ( $\mathrm{n} /$ minggu) berdasarkan jenis perangkap dan spesies serangga di gudang B penyimpanan bungkil kopra. Hasil uji sidik ragam menunjukkan jenis perangkap $\left(\mathrm{F}_{5,77}=30,13\right.$; $\mathrm{P}$ $=0,00)$ dan spesies serangga $\left(\mathrm{F}_{6,77}=5,83 ; \mathrm{P}=\right.$ $0,00)$ memiliki rata-rata serangga tertangkap yang
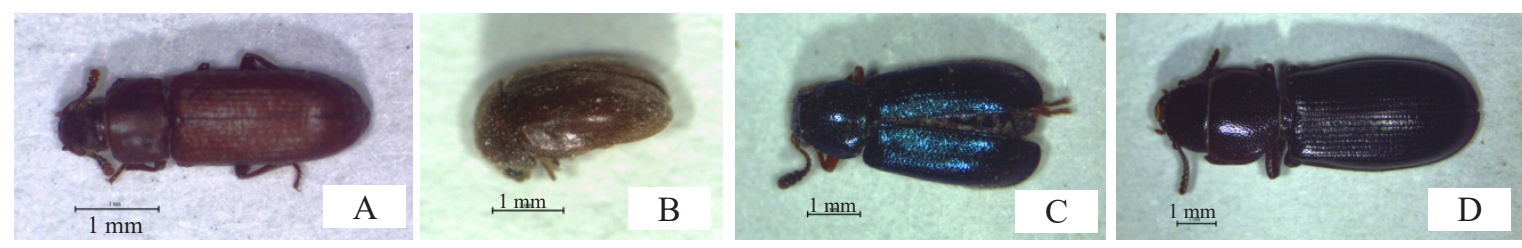

Gambar 3. Spesies serangga Tribolium castaneum (A); Lasioderma serricorne (B); Necrobia rufipes (C); Tenebroides mauritanicus (D).

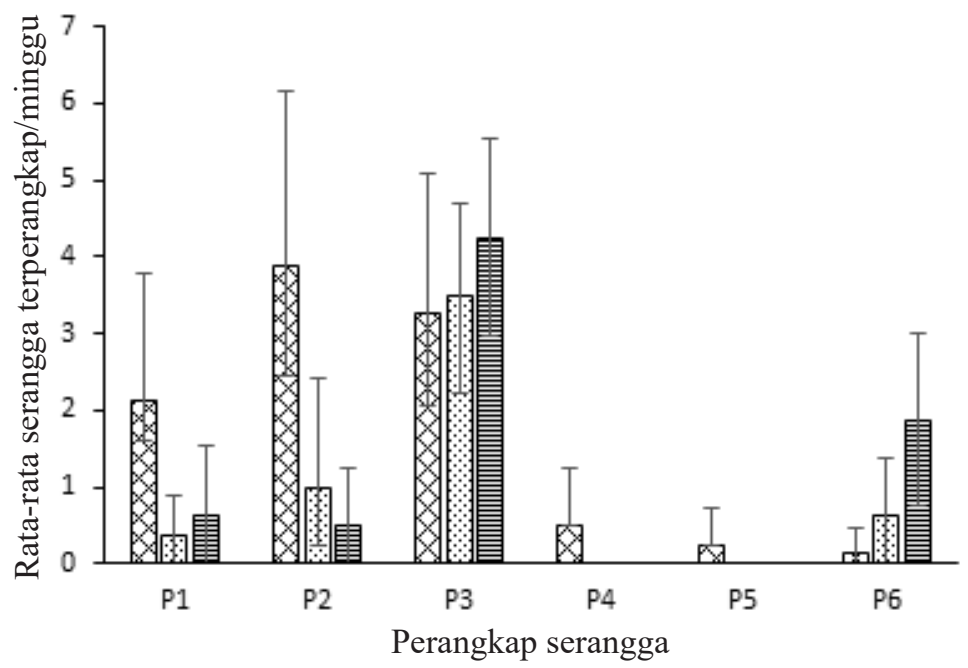

घ'Tribolium castaneum ๑Necrobia rufipes

目Lasioderma serricorne

Gambar 4. Rata-rata serangga yang tertangkap (n/minggu) berdasarkan jenis perangkap dan spesies serangga di gudang A penyimpanan bungkil kopra.

Tabel 3. Rata-rata serangga terperangkap berdasarkan spesies dan jenis perangkap serangga di gudang penyimpanan bungkil kopra $( \pm \mathrm{SD})^{\mathrm{a}}$

\begin{tabular}{lccrrr}
\hline Perangkap & \multicolumn{3}{c}{ Gudang A } & \multicolumn{2}{c}{ Gudang B } \\
\cline { 2 - 6 } serangga & Tc & Nr & Ls & Tc & Tm \\
\hline P1 & $2,1 \pm 1,64 \mathrm{~b}$ & $0,4 \pm 0,52 \mathrm{~b}$ & $0,6 \pm 0,92 \mathrm{c}$ & $9,4 \pm 2,45 \mathrm{a}$ & $3,9 \pm 2,75 \mathrm{c}$ \\
P2 & $3,9 \pm 2,30 \mathrm{a}$ & $1,0 \pm 141 \mathrm{~b}$ & $0,5 \pm 0,76 \mathrm{c}$ & $16,1 \pm 3,56 \mathrm{a}$ & $10,0 \pm 4,78 \mathrm{a}$ \\
P3 & $3,3 \pm 1,83 \mathrm{ab}$ & $3,5 \pm 1,20 \mathrm{a}$ & $4,3 \pm 1,28 \mathrm{a}$ & $12,6 \pm 7,42 \mathrm{a}$ & $6,1 \pm 4,22 \mathrm{ab}$ \\
P4 & $0,5 \pm 0,76 \mathrm{c}$ & $0,0 \pm 0,00 \mathrm{~b}$ & $0,0 \pm 0,00 \mathrm{c}$ & $5,3 \pm 5,15 \mathrm{~b}$ & $0,9 \pm 1,13 \mathrm{~d}$ \\
P5 & $0,3 \pm 0,46 \mathrm{c}$ & $0,0 \pm 0,00 \mathrm{~b}$ & $0,0 \pm 0,00 \mathrm{c}$ & $3,8 \pm 2,31 \mathrm{~b}$ & $1,0 \pm 1,07 \mathrm{~cd}$ \\
P6 & $0,1 \pm 0,35 \mathrm{c}$ & $0,6 \pm 0,74 \mathrm{~b}$ & $1,9 \pm 1,13 \mathrm{~b}$ & $0,3 \pm 0,46 \mathrm{c}$ & $0,4 \pm 0,52 \mathrm{~d}$ \\
\hline
\end{tabular}

Tc: T. castaneum; Nr: N. rufipes; Ls: L. serricorne; Tm: T. mauritanicus.

Angka yang diikuti dengan huruf yang berbeda pada kolom yang sama menunjukkan perbedaan yang signifikan berdasarkan uji Tukey pada taraf 5\%. 
berbeda nyata pada taraf $5 \%$. Perangkap serangga P2 memiliki rata-rata $T$. castaneum (16,1 imago/ minggu) dan T. mauritanicus (10 imago/minggu) tertangkap yang lebih tinggi dibandingkan dengan jenis perangkap serangga lainnya. Hasil uji lanjut menunjukkan rata-rata $T$. castaneum yang tertangkap di perangkap P2 tidak berbeda nyata dengan $\mathrm{P} 1$ dan $\mathrm{P} 3$, tetapi berbeda nyata dengan P4, P5 dan P6. Perangkap P2 memiliki rata-rata $T$. mauritanicus tertangkap yang tidak berbeda nyata dengan P3, tetapi secara signifikan lebih tinggi dibandingkan dengan jenis perangkap serangga lainnya (Tabel 3).

T. castaneum merupakan serangga hama yang dapat ditemukan di kedua gudang penyimpanan bungkil kopra. Hasil uji t menunjukkan rata-rata T. castaneum yang tertangkap pada perangkap colokan di GA secara signifikan lebih rendah dibandingkan dengan pada perangkap colokan di $\operatorname{GB}\left(\mathrm{T}_{8,14}=-8,17 ; \mathrm{P}=0,00\right)$.

\section{PEMBAHASAN}

Serangga $T$. castaneum dan L. serricorne memiliki respons yang berbeda terhadap jenis perangkap pada percobaan di laboratorium. Serangga yang tertangkap lebih banyak dipengaruhi oleh jenis perangkap yang digunakan selama dilakukannya percobaan. Perangkap colokan memiliki jumlah rata-rata yang lebih tinggi dalam memerangkap serangga uji. Hasil penelitian menunjukkan bahwa imago T. castaneum memiliki ketertarikan terhadap benda-benda berbentuk vertikal yang ditemukan pada landscape habitatnya (Semeao et al. 2011). Serangga $T$. castaneum dapat tertarik oleh bentuk vertikal dari perangkap colokan. Serangga-serangga dari famili Tribolium spp. yang hidup di alam memiliki naluri untuk bersembunyi pada pepohonan yang berada di sekitar lingkungannya.

Serangga L. serricorne dibandingkan T. castaneum lebih banyak masuk ke dalam perangkap pada percobaan di laboratorium. Serangga L. serricorne merupakan serangga nokturnal yang lebih banyak aktif pada malam hari dan tertarik dengan cahaya. Serangga T. castaneum tidak memiliki respons positif terhadap cahaya UV di lingkungan sekitarnya. Hasil penelitian menunjukkan $T$. castaneum memiliki ketertarikan yang paling rendah terhadap cahaya UV dari LED UV (0,06\%) dibandingkan dengan gelombang cahaya lampu LED lainnya (Song et al. 2016). Cahaya UV memiliki energi radiasi (foton) yang lebih tinggi dibandingkan dengan cahaya tampak sehingga dapat menyebabkan kerusakan dan degenerasi retina pada mata majemuk seranggaserangga tertentu (Shimoda \& Honda 2013). Serangga $T$. castaneum telah lama beradaptasi pada kondisi lingkungan yang lebih gelap pada habitatnya. Hasil penelitian menunjukkan bahwa cahaya UV A dapat menyebabkan meningkatnya heat shock protein (Hsp) yang dihasilkan oleh stress-responsive gene pada imago T. castaneum sebagai reaksi terhadap kondisi lingkungan yang tidak menguntungkan (Sang et al. 2012).

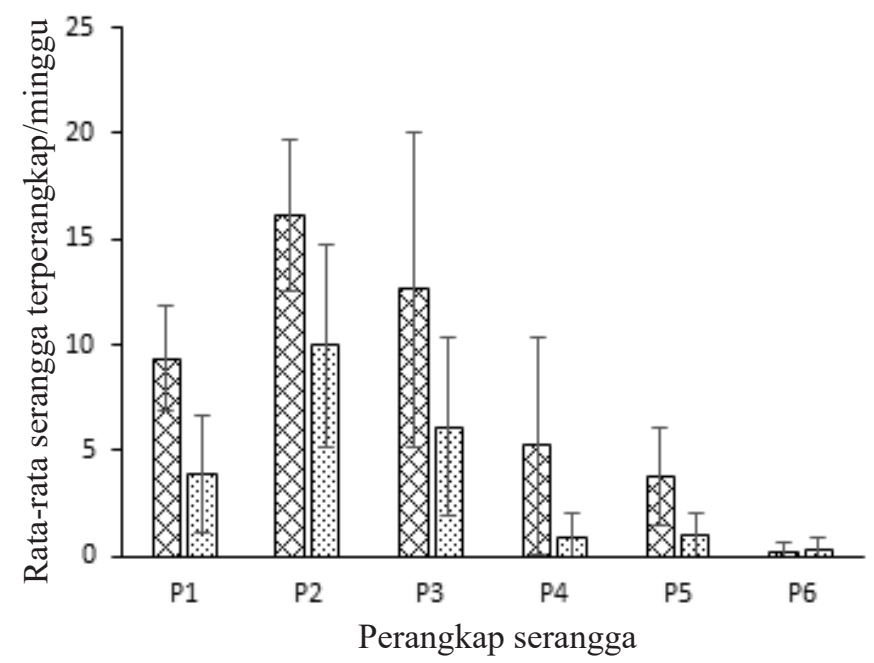

๑'Tribolium castaneum

Đenebroides mauritanicus

Gambar 5. Rata-rata serangga yang tertangkap (n/minggu) berdasarkan jenis perangkap dan spesies serangga di gudang B penyimpanan bungkil kopra. 
Serangga yang terperangkap di GA memiliki komposisi spesies serangga yang berbeda dengan di GB. Hasil survei serangga yang dilakukan pada 8 gudang penyimpanan pakan ternak menunjukkan indeks keanekaragaman spesies (indeks Simpson's) yang bervariasi, yaitu antara 0,39 (rendah) sampai dengan 0,81 (tinggi). Serangga yang terperangkap berbeda baik dalam jumlah maupun komposisi spesies di antara gudang penyimpanan pakan ternak berkaitan erat dengan lokasi, jenis pakan ternak, manajemen pengendalian hama, dan tingkat sanitasinya (Larson et al. 2008). Komoditas bungkil kopra yang disimpan dan kondisi lingkungan di dalam gudang penyimpanan menjadi tempat yang menarik bagi beberapa spesies serangga hama gudang. Komoditas bungkil kopra merupakan sumber makanan yang sesuai untuk serangga hama gudang sekunder, seperti $T$. castaneum. Hasil penelitian menunjukkan bahwa serangga L. serricorne merupakan serangga hama minor pada komoditas bungkil kopra yang disimpan di Malaysia (Semple 1985). Serangga L. serricorne lebih banyak mengonsumsi air daripada makanan setelah menjadi imago yang berkisar antara 18-46 hari (Mahroof \& Phillips 2008).

Perangkap colokan dirancang berdasarkan hasil pengamatan yang menunjukkan $T$. castaneum lebih banyak beraktivitas di sekitar komoditas pertanian yang disimpan dan bersembunyi di retakan dinding atau lantai gudang penyimpanan. Serangga $T$. castaneum tidak aktif terbang, tetapi lebih banyak berjalan ketika bergerak dari satu tempat ke tempat lainnya. Imago $T$. castaneum dapat terperangkap ke dalam perangkap colokan setelah masuk melalui lubang-lubang yang terdapat di perangkap colokan. Hasil penelitian menunjukkan bahwa rata-rata serangga $T$. castaneum terperangkap tidak dipengaruhi oleh jumlah lubang-lubang perangkap yang berbeda antara perangkap colokan dan perangkap jebakan (Epsky \& Shuman 2002).

Serangga $T$. castaneum yang terperangkap pada perangkap colokan P2 berbeda nyata dibandingkan dengan perangkap serangga lainnya pada tingkat populasi yang rendah di GA. Manajemen pengendalian hama dan ketersediaan bungkil kopra di GA merupakan faktor yang dapat menekan meningkatnya perkembangan populasi T. castaneum. Komoditas bungkil kopra sering tidak tersedia di gudang A karena fasilitas penyimpanan di gudang A hanya digunakan untuk menyimpan bungkil kopra yang akan diekspor. Komoditas bungkil kopra yang tidak terdapat di GA yang dapat berlangsung selama lebih dari satu bulan dapat memutus siklus hidup T. castaneum yang berkisar antara 26-30 hari (Devi \& Devi 2015). Tindakan pencegahan terhadap masuknya serangga dilakukan dengan memasang tirai plastik pada setiap pintu masuk dan memberi warna biru pada dinding di GA. Serangga T. castaneum berdasarkan hasil penelitian tidak menyukai warna-warna yang cerah pada kemasan makanan yang disimpan (Chukwulobe \& Echezona 2014). Komoditas bungkil kopra yang disimpan diatur supaya tidak menyatu pada dinding, tetapi terdapat jarak sekitar satu meter antara tumpukan bungkil kopra dan dinding gudang penyimpanan. Tindakan sanitasi dan pemeriksaan menjadi lebih mudah karena terdapat cukup ruang yang dapat digunakan di sepanjang dinding di GA. Tindakan sanitasi juga dilakukan dengan menggunakan air bertekanan tinggi di sekitar area GA untuk membersihkan sisa-sisa bungkil kopra yang tercecer setelah bungkil kopra dimuat ke atas kapal laut.

Serangga $T$. castaneum lebih banyak terperangkap pada tingkat kepadatan populasi yang tinggi. Komoditas bungkil kopra disimpan dengan memaksimalkan kapasitas penyimpanan yang ada di GB sehingga tidak terdapat ruang antara dinding dan tumpukan bungkil kopra. Komoditas bungkil kopra yang tersimpan dalam waktu yang cukup lama menjadi tempat yang menguntungkan bagi perkembangan populasi T. castaneum. Hasil penelitian menunjukkan pada populasi $T$. castaneum yang tinggi di gudang penyimpanan akan banyak ditemukan juga T. mauritanicus di area tersebut. Hasil pengamatan menunjukkan $T$. mauritanicus merupakan serangga hama sekunder yang juga bersifat predator terhadap serangga lainnya (Coskuncu \& Kovanci 2005).

\section{KESIMPULAN}

Perangkap colokan lebih efektif dalam mendeteksi T. castaneum dan T. mauritanicus dibandingkan dengan perangkap jebakan 
maupun light trap dengan lampu UV. Serangga T. castaneum dan T. mauritanicus merupakan serangga hama utama yang menyerang komoditas bungkil kopra di gudang penyimpanan. Perangkap colokan yang dimodifikasi dengan light trap LED UV dapat menangkap lebih banyak L. serricorne dan $N$. rufipes dibandingkan dengan perangkap jebakan maupun perangkap colokan.

\section{UCAPAN TERIMA KASIH}

Terima kasih kepada Badan Karantina Pertanian, Kementerian Pertanian Republik Indonesia yang telah mendanai penelitian ini. Ucapan terima kasih juga disampaikan kepada SEAMEO BIOTROP, Laboratorium Balai Karantina Pertanian Kelas I Manado, dan dua gudang kopra di Bitung Sulawesi Utara yang telah memberikan izin penggunaan fasilitas untuk pelaksanaan penelitian ini.

\section{DAFTAR PUSTAKA}

Baehaki SE, Iswanto EH, Munawar D, Sumaryono N. 2016. Light traps abilities of mercury (ML160 Watt) BSE models and light traps of solar cell (CFL-20 Watt) to capture of pests in the rice field. American Journal of Engineering Research 5:138-144.

[BKP] Badan Karantina Pertanian. Kementerian Pertanian. 2014. Pedoman Sertifikasi Fitosanitari. Palm Kernel Expeller (PKE) Tujuan New Zealand. Jakarta: Kementan.

Bousquet Y. 1990. Beetles Associated with Stored Products in Canada: An Identification Guide. Ottawa: Research Branch Agriculture Canada.

Buckman KA, Campbell JF. 2013. How varying pest and trap densities affect Tribolium castaneum capture in pheromone traps. Entomologia Experimentalis et Applicata 146:404-412. doi: https://doi.org/10.1111/eea.12039.

Chukwulobe MN, Echezona BC. 2014. Responses of Tribolium castaneum (Herbst.) (Coleoptera: Tenebrionidae) to coloured polyethylene films in storage of musa chips. World Journal of Agricultural Research 2:51-55. doi: https://doi. org/10.12691/wjar-2-2-4.

Coskuncu KS, Kovanci B. 2005. Studies on the biology and distribution of cadelle, Tenebroides mauritanicus (L.) (Coleoptera: Trogossitidae) in Bursa, Turkey. Journal of Entomology 2:1720. doi: https://doi.org/10.3923/je.2005.17.20

Damanik. 2000. Keterkaitan penawaran kelapa untuk memenuhi permintaan industri minyak kelapa dan industri makanan-minuman. Info Sosial Ekonomi 1:1-20.

Devi MB, Devi NV. 2015. Biology of rust-red lour beetle, Tribolium castaneum (Herbst) (Coleoptera: Tenebrionidae). Biological Forum - An International Journal 7:12-15.

[Dirjenbun] Direktorat Jenderal Perkebunan. Kementerian Pertanian. 2017. Statistik Perkebunan Indonesia Komoditas Kelapa 20152017. Jakarta: Kementan.

Epsky ND, Shuman D. 2002. Hole density and capture of stored-product insect pests in grain probe traps. Journal of Econonomic Entomology. 95:1326-32. doi: https://doi.org/10.1603/00220493-95.6.1326.

Kaunang WRCh. 2013. Daya saing ekspor komoditi minyak kelapa Sulawesi Utara. Jurnal EMBA 1:1304-1316.

Larson Z, Subramanyam B, Herrman T. 2008. Stored-product insects associated with eight feed mills in the Midwestern United States. Journal of Economic Entomology 101:998-1005. doi: https://doi.org/10.1093/jee/101.3.998.

Mahroof RM, Phillips TW. 2008. Life history parameters of Lasioderma serricorne (F.) as influenced by food sources. Journal of Stored Products Research 44:219-226. doi: https://doi. org/10.1016/j.jspr.2007.12.001.

Papadopoulou SC, Buchelos CT.2002. Comparison of trapping efficacy for Lasioderma serricorne (F.) adults with electric, pheromone, food attractant and control-adhesive traps. Journal of Stored Product Research 38:375-383. doi: https://doi. org/10.1016/S0022-474X(01)00039-X.

Sang W, Ma W, Qiu L, Zhu Z, Lei C. 2012. The involvement of heat shock protein and cytochrome P450 genes in response to UV-A exposure in the beetle Tribolium castaneum. Journal of Insect Physiology 58:830-836. doi: https://doi.org/10.1016/j.jinsphys.2012.03.007.

SemeaoAA, CampbellJF, Whitworth RW, Sloderbeck PE. 2011. Response of Tribolium castaneum and Tribolium confusum adults to vertical black shapes and its potential to improve trap capture. Journal of Stored Product Research 47:88-94. doi: https://doi.org/10.1016/j.jspr.2011.01.002.

Semple RL. 1985. Problems relating to pest control and use of pesticides in grain storage: the current 
situation in ASEAN and future requirements. Di dalam: Champ BR, Highley E (Ed.), Pesticides and Humid Tropical Grain Storage Systems. Proceedings of an International Seminar, (Manila, 27-30 May 1985). hlm. 55. Manila: Australian Centre for International Agricultural Research.

Shimoda M, Honda K. 2013. Insect reactions to light and its applications to pest management. Application Entomology Zoology 48:413-421. doi: https://doi.org/10.1007/s13355-013-0219-x.

Song J, Jeong EY, Lee HS. 2016. Phototactic behavior 9: phototactic behavioral response of Tribolium castaneum (Herbst) to light-emitting diodes of seven different wavelengths. Journal of Application Biology Chemistry 59:99-102. doi: https://doi.org/10.3839/jabc.2016.018.
Toews MD, Phillips TW, Payton ME. 2005. Estimating populations of grain beetles using probe traps in wheat-filled concrete silos. Enviromental Entomology 34:712-718. doi: https://doi.org/10.1603/0046-225X-34.3.712.

[USDA] United States Department of Agricultural Research Service. 1991. Di dalam: Gorham JR (Eds.), Insect and Mite Pests in Food an Illustrated Key. Gorham JR (Eds.). hlm.142190. Washington: USDA. 